\title{
The "Sale" of Conditional Citizenship: the Cyprus Investment Programme under the Lens of EU Law
}

\author{
Sofya Kudryashova*
}

The rise of investment migration has become subject to intense study worldwide. These schemes are characterised as an 'exchange of national membership rights for immigrants' financial and human capital' and have been introduced worldwide with great success, especially in North and Latin America. ${ }^{1}$ Despite facing criticism, ${ }^{2}$ the increasing popularity of investment migration

* Corporate Administrator at PHC Tsangarides LLC. I would like to express my gratitude to Professor Dimitry Kochenov for his guidance and encouragement throughout the entire process of writing this article. All views expressed herein are personal.

1 Gramlen, A., Kutarna, C. and Monk, A. H. B. (2016). Re-thinking Immigrant Investment Funds. Investment Migration Working Papers No. 2016/1; Antigua and Barbuda Citizenship by Investment (Amendment) Act (2016) published in the Official Gazette, Vol 36; Dominica Economic Citizenship Program, available at http://www.dominicacitizenshipbyinvestment. com; Barzey, U. P. (2015). 4 Caribbean Citizenship By Investment Programs, available on https://www.caribbeanandco.com/4-caribbean-citizenship-by-investment-programs; Valencia, M. (2017). Passports for cash: Citizens of Anywhere, available at https://www.1843magazine.com/features/citizens-of-anywhere; Krakat, M. B. (2018). Genuine Links beyond State and Market Control: The Sale of Citizenship by Investment in International and Supranational Legal Perspective. Bond Law Review 3 o.

2 Schachar, A. (2018). Dangerous Liaisons: Money and Citizenship, in Bauböck, R. (ed), Debating Transformations of National Citizenship. Springer, Cham, pp. 11-12; Barbulescu, R. (2018). Global mobility corridors for the ultra-rich. The neoliberal transformation of citizenship, in Bauböck, R. (ed), Debating Transformations of National Citizenship. Springer, Cham, pp. 29; Scherrer, A. and Thirion, E. (2018). Citizenship by Investment (CBI) and Residency by Investment (RBI) schemes in the EU. European Parliamentary Research Service (PE 627.128), pp. 20-25; Cooper, H. (2016). ME P S Slam Cypriot Citizenship-For-Sale Scheme. https://www. politico.eu/article/meps-slam-cypriot-citizenship-for-sale-scheme-schengen-area/; Mavelli, L. (2018). Citizenship for Sale and the Neoliberal Political Economy of Belonging. International Studies Quarterly, pp. 1, 4-5; Parker, O. (2016). Commercializing Citizenship in Crisis EU: The Case of Immigrant Investor Programmes. Journal of Common Market Studies 55,

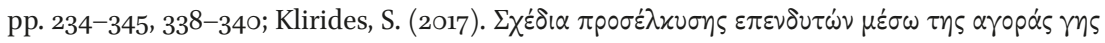

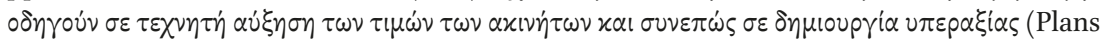
to attract investors through the land market lead to artificially rising property prices and the creation of overvaluation), available on http://www.eurokerdos.com/provlima-ta-diavatiria/. 
schemes has reached the EU, with Austria, Malta and the Republic of Cyprus (hereinafter 'Cyprus' or 'Republic') being the leading Member States granting national and therefore EU citizenship to third-country nationals in exchange for financial contribution to their economies. ${ }^{3}$ Cyprus, a member of the Union since 2004, introduced its Investment Programme in 2013, which has changed over the years and the newest amendments were imposed as of $15^{\text {th }}$ of May 2019. ${ }^{4}$ As the Programme is proving successful in attracting foreign investors, ${ }^{5}$ the importance of examining the potential legal issues originating from the criteria imposed on applicants and their aftermath under EU law is indisputable to ensure its legality. The strict territorial link to the institution of citizenship ${ }^{6}$ as an attribute of state sovereignty ${ }^{7}$ has been loosened through the formation of polities beyond the state, with the emergence of the EU and the institution of Union citizenship ${ }^{8}$ as prime examples. The criteria imposed on applicants are to a certain extent similar to those of other investment migration programmes, a topic elaborated in the first section of this article. However, two elements of the Programme are open to question: first, applicants must retain residential property permanently in the Republic to preserve their citizenship status and second, non-compliance with

3 Surak, K. (2016). Global Citizenship 2.o: The Growth of Citizenship by Investment Programmes. IMC-RP 2016/3, pp. 16-17, 21, 24-25; Baaren, L. and Li, H. (2018). Wealth Influx, Wealth Exodus: Investment Migration from China to Portugal. IMC-RP 2018/1, pp. 2-3; Dzankic, J. (2012). The Pros and Cons of Ius Pecuniae: Investor Citizenship in Comparative Perspective. EUI Working Papers RSCAS 2012/14, pp. 11-13; Parker (n 2), pp. 335.

4 Extract from the minutes of the Ministerial Council Meeting Dated 13/2/2019, The Cyprus Investment Programme, Decision Number 86.879, available on http://www.cm.gov.cy/ cm/cm.nsf/All/B $374 \mathrm{~F}_{161 F} \mathrm{~F}_{3} \mathrm{~F}_{3} \mathrm{Ao}_{7} \mathrm{C}_{225}{ }_{3} \mathrm{~F}_{3} \mathrm{OO} 273513 /$ file/86\%20879.pdf?Open Element; Cyprus Investment Programme on the basis of subsection (2) of section 111A of the Civil Registry Laws of 2002-2019' available on http://www.moi.gov.cy/moi/moi.nsf/all/A54823EFD5AA75DDC22583FEoo224C1F/\$file/CYPRUS\%2OINVESTEMENT\%2OPROGRAMME_ 15.5.2019.pdf?openelement.

5 Farolfi, S., Harding, L. and Orphanides, S. (2018). EU Citizenship for sale as Russian oligarch buys Cypriot passport, available on https://www.theguardian.com/world/ 2018/mar/o2/eu-citizenship-for-sale-as-russian- oligarch-oleg-deripaska-buys-cypriot-

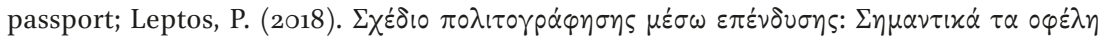
$\gamma(\alpha \tau \eta \nu$ oı $о$ vo $\mu i \alpha$ (Scheme for naturalisation through investment: significant benefits for the economy), available on https://inbusinessnews.reporter.com.cy/opinions/article/ 183434/schedio- politogafisis-meso-ependysis-simantika-ta-ofeli-ga-tin-oikonomia.

6 Brubaker, R. (1992). Citizenship and Nationhood in France and Germany. Harvard University Press, pp. 23-26.

7 Kochenov, D. (2009). Ius Tractum of Many Faces: European Citizenship and the Difficult Relationship between Status and Rights. Columbia Journal of European Law 15, pp. 178.

8 Kochenov (n 7), pp. 181. 
the criterion mentioned results in the retroactive revocation of their Cypriot and EU citizenship.

This article analyses the legal implications of the acquisition of EU citizenship through the Cyprus Investment Programme in light of EU law, particularly on the free movement of capital and citizenship. Accordingly, by focusing on the abovementioned aspects, two principal questions will be addressed:

1. Does the requirement to permanently own residential property in $\mathrm{Cy}$ prus result in a violation of the free movement of capital under EU law?

2. Does the possibility of revocation of Cypriot nationality for non-compliance with the abovementioned requirement violate the principles established in EU citizenship case law?

To answer the first question, section two will focus on the origins of the freedom of movement of capital and on the constraints imposed on it by the Programme's requirements. Following a close examination of the case law of the Court of Justice of the European Union (the 'CJEU' or 'the Court'), the underlying presumption that economic objectives cannot justify restrictions on capital movements ${ }^{9}$ will aid in the assessment of the legality of the Programme. The following section examines the second question; throughout its evolution in the case law of the CJEU and the work of legal scholars, Union citizenship has acquired a unique status which is not a mere extension of the Member States' nationalities. ${ }^{10}$ The applicability of Union law in matters of citizenship was established in Micheletti, ${ }^{11}$ and the material scope of Union citizenship was further expanded in Rottmann ${ }^{12}$ and Ruiz Zambrano. ${ }^{13}$ The evaluation of the legality of the Cyprus Investment Programme in light of EU citizenship case law will show that Cyprus cannot take measures which will undermine the rights attached to EU citizenship, nor should it place its citizens under a legal regime, which would not allow the future prospect of exercising the said

9 Court of Justice, judgment of 4 June 2002, case C-367/98, Commission v Portuguese Republic, para $5^{2 .}$

10 Szpunar, M. and Blas López, M. E. (2017). Some Reflections on Member State Nationality: A Prerequisite of EU Citizenship and an Obstacle to Its Enjoyment, in Kochenov, D. (ed), EU Citizenship and Federalism: The Role of Rights. Cambridge University Press, pp. 111-112.

11 Court of Justice, judgment of 7 July1992, case C-369/9o Mario Vicente Micheletti and others $v$ Delegación del Gobierno en Cantabria.

12 Court of Justice, judgment of 2 March 2010, case C-135/08 Janko Rottmann v Freistaat Bayern.

13 Court of Justice, judgment of 8 March 2011, case C-34/og Gerardo Ruiz Zambrano v Office national de l'emploi (ONEm). 
rights. ${ }^{14}$ In this regard, the status and the rights of the family members of the investor will also be taken into consideration and the Rottmann criteria will be applied by analogy to the Cyprus Investment Programme. Its examination in light of the abovementioned will lead to conclusions suggesting an urgent need to amend the Programme in order to comply with Union law.

\section{The Unique Case of the Cyprus Investment Programme}

Before going through the specific attributes of the Investment Programme introduced in Cyprus, it is important to set out the geopolitical conditions of the island in order to understand its relationship with the Union and the context in which the Programme will be analysed.

Following the Turkish military intervention in 1974 and the unrecognised declaration of independence of the Turkish Republic of Northern Cyprus (hereafter 'the TRNC') in $1983,{ }^{15}$ Cypriot membership of the EU was achieved in 2004, but the application of the acquis communitaire is suspended in the northern part of the island's territory. ${ }^{16}$ The status of the TRNC is a unique case in the $\mathrm{EU}$, very different to that enjoyed in the outermost regions ${ }^{17}$ or overseas territories ${ }^{18}$ of its other Member States, as the suspension of the acquis there is

14 Kochenov, D. (2011). A Real European Citizenship: A New Jurisdiction Test: A Novel Chapter in the Development of the Union in Europe. Columbia Journal of European Law 14, pp. 94, 96.

15 Ker-Lindsay, J. (2011). The Cyprus Problem: What Everyone Needs to Know. Oxford University Press, pp. $5^{-6 .}$

16 Act concerning the conditions of accession of the Czech Republic, the Republic of Estonia, the Republic of Cyprus, the Republic of Latvia, the Republic of Lithuania, the Republic of Hungary, the Republic of Malta, the Republic of Poland, the Republic of Slovenia and the Slovak Republic and the adjustments to the Treaties on which the European Union is founded - Protocol No 10 on Cyprus [2003] OJ L 236, 23.9.2003.

17 In Outermost Regions (9) EU law applies according to Article 355 (1) TFEU, under conditions laid down by the Council in Regulations 1447/2001, 1448/2001, 1449/2001, 1450/2001, 1451/2001, [2001] OJ L198/1 and Regulations 1452/2001, 1453/2001, 1454/2001, [2001] OJ L 198, 21.07.2001. See Skoutaris, N. (2017). Territorial Differentiation in EU Law: Can Scotland and Northern Ireland Remain in the EU and/or the Single Market? Cambridge Yearbook of European Legal Studies 19, pp. 300; For more information on the status of Outermost Regions see Omarjee, I. (2011). Specific Measures for the Outermost Regions after the Entry into Force of the Lisbon Treaty, in Kochenov, D. (ed) EU Law of the Overseas: Outermost Regions, Associated Overseas Countries and Territories, Territories Sui Generis. Wolters Kluwer, Leiden, pp. 121-136.

18 These are territories where the applicability of EU law is governed by Part 4 of the TFEU and their corresponding association agreements. See Skoutaris, N. (2017). Territorial Differentiation in EU Law: Can Scotland and Northern Ireland Remain in the EU and/ 
a consequence of a military intervention..$^{19}$ It has been acknowledged that the area is under the effective control of Turkey ${ }^{20}$ and as a consequence, a special regime has been established for the Turkish-Cypriot community residing in the north of the island. Although, the status of Union citizenship of Turkish Cypriots and the rights it entails are uncontested, they remain in 'hibernation'21 $^{21}$ as long as they reside in the TRNC, because the protection of their rights there falls under the jurisdiction of Turkey. ${ }^{22}$ To provide certain guarantees for the enjoyment of EU rights for such citizens, the Union adopted the Green Line Regulation on the administration of the rules concerning the crossing of the line dividing the island. ${ }^{23}$ It is worth mentioning that the Green Line does not constitute a border in the EU; 24 it authorises Cyprus to impose checks on the crossing of persons, goods and services that originate or have as their destination the TRNC. ${ }^{25}$ Due to this state of affairs, the Investment Programme discussed in this article is enforced only in the southern part of the territory of Cyprus, as that is the only area of the island where the Cypriot government exercises effective control and where EU law is applied in its entirety.

or the Single Market? Cambridge Yearbook of European Legal Studies 19, pp. 301-302. For more information on the status of the Overseas Territories see Clegg, P. (2013). European Integration and Postcolonial Sovereignty Games: The EU Overseas Countries and Territories. The Round Table, pp. 492-494; Tryfonidou, A. (2010). The Free Movement of Goods, the Overseas Countries and Territories, and the EU's Outermost Regions: Some Problematic Aspects. Legal Issues of Economic Integration 37, pp. 317-338; Kochenov, D. (2011). EU Law of the Overseas: Outermost Regions, Associated Overseas Countries and Territories, Territories Sui Generis. Wolters Kluwer, Leiden, pp. 47-50.

19 Skoutaris, N. (2011). The Cyprus Issue: The Four Freedoms in a Member State Under Siege. Oxford University Press, pp. 52-54.

$20 \quad$ Art. 1, Protocol 10 on Cyprus (n 16); Skoutaris, N. (2005). Differentiation in European Union Citizenship l aw: The Cyprus Problem, in Inglis, K. and Ott, A. (eds), The Constitution for Europe and an Enlarging Union: Union in Diversity? Europa Law Publishing, pp. 172-173; European Court of Human Rights, decision of 23 March 1995, no 15318/89, Titina Loizidou $v$ Turkey, para 56 .

21 Skoutaris (n 19), pp. 65.

22 Skoutaris (n 19), pp. 55-56.

23 Council Regulation (EC) 866/2004 of 29 April 2004 on a regime under Article 2 Protocol 10 to the Act of Accession, 'Green Line Regulation' [2014] OJ L 206; Skoutaris (n 20), pp. 171-172.

24 Council Regulation (EC) 866/2004 of 29 April 2004 on a regime under Article 2 Protocol 10 to the Act of Accession, 'Green Line Regulation' [2014] OJ L 206, 9.6.2004, recital 7; Laulhé-Shaelou, S. (2010) The EU and Cyprus: Principles and Strategies of Full Integration. Brill, pp. 270.

25 Council Regulation (EC) 866/2004 of 29 April 2004 on a regime under Article 2 Protocol 10 to the Act of Accession, 'Green Line Regulation' [2014] OJ L 206, 9.6.2004, titles II-IV; Skoutaris (n 19), pp. 111-114. 
The Investment Programme has been variously amended since its adoption in 2013 by the Cypriot Council of Ministers, before culminating in its current version in May 2019. ${ }^{26}$ According to this Programme, any third-country national can acquire Cypriot and therefore EU citizenship if they meet certain economic criteria such as investment in real estate, land development and infrastructure projects, the purchase or establishment or participation in Cypriot companies or businesses, or investment in alternative investment funds or financial assets in Cypriot companies or organisations. The investment funds must be at least EUR 2 million and must be retained in the Republic for a period of at least 5 years from the date of naturalisation. ${ }^{27}$ The latest amendment to the Programme this year introduced an additional economic criterion for applicants: donation of EUR 75.00o to the Research and Innovation Foundation and EUR 75.00o the Cyprus Land Development Corporation for the financing of housing schemes for affordable housing in the Republic.

Further obligations are imposed on the applicants, incorporated in the terms and conditions of the Programme. These include due diligence checks, the possession of a residence permit in Cyprus, a declaration of having no other applications for citizenship rejected in other EU Member States and most importantly with respect to this article, residential property which the applicant must retain ownership of. Residence permits are granted to third-country nationals already living in the Republic in accordance with Regulation 1030/2002, ${ }^{28}$ but for the purposes of acquiring Cypriot nationality through investment, an immigration permit is granted to applicants on the basis of Regulation 6(2) of the national Aliens and Immigration Law. ${ }^{29}$ The criteria for the acquisition of an immigration permit are included in sections A and B of the Investment Programme, in addition to requirements for a number of financial guarantees such as secure annual income and property title deeds. ${ }^{30}$ According to the Programme, if naturalisation is declined or revoked, the immigration permit obtained for the purposes of naturalisation will also be nullified. ${ }^{31}$ The due diligence checks have also been recently

\footnotetext{
26 Cyprus Investment Programme (n 4$)$.

27 Cyprus Investment Programme (n 4$)$.

28 Council Regulation (EC) of 13 June 2002 laying down a uniform format for residence permits for third- country nationals [2002] OJ L 157, 15.6.2002.

$292^{\text {nd }}$ Revision of the Criteria for Granting an Immigration Permit within the Scope of the Expedited Procedure to Applicants who are Third-Country Nationals and Invest in Cyprus [2016], available at http://www.moi.gov.cy/moi/CRMD/crmd.nsf/All/ 6E845849175A310DC2257F7Doo3oF4FE?OpenDocument.

$30 \quad$ Ibid, Section 2.

31 Cyprus Investment Programme (n 4), pp. 4.
} 
enhanced, with the creation of an independent governmental body that will examine applicants' admissibility in the future. All applicants must possess a recent clean criminal record, should not hold the status of politically exposed persons and should not be included in the list of persons whose assets have been frozen within the EU as a result of sanctions, in accordance with Directive $2014 / 42 / E U, 32$ or had any sanctions imposed by third countries and international organisations, as all of the abovementioned will render their application inadmissible. ${ }^{33}$

As for the purchase of permanent residential property, it should be worth at least EUR 500,000 (plus VAT) and must be retained in the Republic permanently. ${ }^{34}$ It is also noted that if the applicant is investing in housing units, which have already been used for the purpose of naturalizing under this Programme, the investment amount rises to EUR 2.5 million, which also includes the EUR 500.00o housing unit. The indefinite ownership of a residence in $\mathrm{Cy}$ prus is a crucial requirement for both admissibility and for the retention of citizenship. The Programme clearly states that where periodic checks discover that any criterion or term and condition ceased to be complied with, naturalisation will be revoked. This is in accordance with Article 54(4) of the General Principles of the Administrative Law of Cyprus, which permits the revocation of any administrative decision in situations where the factual circumstances constituting the basis of the decision or which constituted the conditions for the issuance of that decision have changed..$^{35}$ In practice, resale of the property is allowed only when it is followed by the purchase of other residential property in the Republic for the applicant's personal use.

This Programme provides the possibility of investing in Cyprus, however obliges applicants to lock part of their investment within its borders, and as a result, obtain Union citizenship, the status of which is enduringly upon the ongoing ownership of one housing unit. These two issues are crucial when examining the Programme in light of the right to the free movement of capital and EU citizenship law respectively, both of which will be analysed in the following sections.

32 Directive 2014/42/EU of the European Parliament and of the Council of 3 April 2014 on the freezing and confiscation of instrumentalities and proceeds of crime in the European Union [2014] OJ L 127, 29.4.2014.

33 Council of Ministers Meeting of 25.7.2019, Evaluation of applications for the assignment of Cypriot citizenship to non-Cypriots/Cypriots on the basis of Cyprus Investment Programme by high risk applicants/ applicants, available in Greek at http://www.cm.gov. cy/cm/cm.nsf/index_19/index_19?OpenForm.

34 Cyprus Investment Programme (n 4), pp. 3-4.

35 Art. 54(A), General Principles of Administrative Law 158(I)/1999. 


\section{Restrictions on Free Movement of Capital}

\section{I.1 Capital Movement, Its Restrictions and Justifications}

The internal market of the Union is an area without internal frontiers, which ensures the free movement of goods, persons, services and capital. ${ }^{36}$ Article 63 TFEU sets out the prohibition on all restrictions on capital movement between the Member States and between the Union and third countries. The lack of an exact definition of capital movement in the Treaties led to the adoption of Directive 88/361/EEC which provides an explanatory Nomenclature in its first Annex. ${ }^{37}$ The list provided for in the annex is not exhaustive, but offers an adequate explanation of the types of capital movement available..$^{38}$ Relevant to this article are the definitions of Direct Investment and Investment in Real Estate, the meanings of which are provided in the explanatory notes. ${ }^{39}$ Direct investment includes investments by all kinds of natural or commercial undertakings, which enable the establishment of lasting and direct links between the undertaking and the entrepreneur to which the capital is made available, in order to carry on an economic activity. Investment in real estate is the purchase of buildings and land for personal use. ${ }^{40}$ These are wide definitions and must be interpreted accordingly.

The CJEU was called upon to provide guidance to the Member States in numerous cases regarding the nature of restrictions prohibited by Article 63 TFEU. The Court insists on a broad interpretation of the freedom and its possible restrictions, ${ }^{41}$ since the proper functioning of the internal market relies on free capital movement in combination with the free movement of persons, goods and services. ${ }^{42}$ The first identified restriction to the free movement of

$36 \quad$ Art. $26(2)$ TFEU.

37 Council Directive 88/361/EEC of 24 July 1988 for the implementation of Article 67 of the Treaty [1988] OJ L 178, 8.7.88, art. 1, para. 1, Annex I; Usher, J. A. (2007). The Evolution of Free Movement of Capital. Fordham International Law Journal 31, pp. 1537-1538.

38 Ibid, pp. 1537-1538; Baber, G. (2014). The Free Movement of Capital and Financial Services: An Exposition? Cambridge Scholars, pp. 26.

39 Council Directive 88/361/EEC of 24 July 1988 for the implementation of Article 67 of the Treaty [1988] OJ L178/5, explanatory notes.

40 Ibid.

41 Horsley, T. (2012). The Concept of an Obstacle to Intra-EU Capital Movement in EU Law, in Nic Shuibhne, N. and Gormley, L.W. (eds), From Single Market to Economic Union: Essays in Memory of John A. Usher. Oxford University Press, pp. 163-164.

42 Hindelang, S. (2009). The Free Movement of Capital and Foreign Direct Investment: The Scope of Protection in EU law. Oxford Scholarship Online. pp. 128; Andenæs, M., Gütt, T. and Pannier, M. (2005). Free Movement of Capital and National Company Law. European Business Law Review 16, pp. 758. 
capital was discrimination between domestic and cross-border movement and between two cross-border movements. ${ }^{43}$ However, to extend the protective nature of the freedom, the Court has broadened its scope so that it goes beyond the notion of non-discrimination. In Commission v France, it ruled that the prohibition of restrictions of capital movement 'goes beyond the mere elimination of unequal treatment ${ }^{44}$ and has reaffirmed the non-hindrance test ${ }^{45}$ in Commission $v$ Portuguese Republic, where it established that a regulation which restricts the possibility for foreign investors to acquire shares in certain Portuguese undertakings is:

[...] capable of impeding capital movements and dissuading individuals in other Member States from investing. ${ }^{46}$

Such a regulation may render the free movement of capital illusory and therefore violate Article 63 TFEU. Other examples of the application of the nonhindrance test include a requirement for prior authorisation for the acquisition of a plot of land in order to demonstrate that the planned acquisition will not be used to establish a secondary residence in Konle, ${ }^{47}$ and a requirement for the security of a mortgage debt, payable in the currency of another Member State, to be registered in the national currency in Trummer and Mayer. ${ }^{48}$

Derogations to the free movement of capital are allowed if they fall under the reasons listed in Article 65 TFEU; otherwise, they must be justified on the basis of overriding public interests and objective reasons on grounds of public policy and public security within the meaning of the case law of the CJEU. ${ }^{49} \mathrm{In}$ principle, it is up to the Member States to 'decide on the degree of protection under which they wish to afford to such legitimate interests', but they must do so within the limits of EU law, particularly by complying with the principle of

\footnotetext{
43 Hindelang (n 42), pp. 130-131.

44 Court of Justice, judgment of 4 June 2002, case C-483/99 Commission v France, paras 40-41.

45 de Luca, A. (2012). New Developments on the Scope of the EU Common Commercial Policy Under the Lisbon Treaty, in Sauvant, K. P. (ed), Yearbook on International Investment Law and Policy. Oxford University Press, pp. 189-191; Horsley (n 41), pp. 164.

46 Court of Justice, judgement of 4 June 2002, case C-367/98 Commission v Portuguese Republic, paras 9-12, 44-45.

47 Court of Justice, judgment of 1 June 1999, case C-302/97 Klaus Konle v Republik Österreich, para 39 .

48 Court of Justice, judgment of 16 March 1999, case C-222/97 Manfred Trummer and Peter Mayer, para 28.

49 C-302/97 Konle para 40; Court of Justice, judgment of 21 December 2011, case C-271/o9 Commission $v$ Republic of Poland, para 55 .
} 
proportionality. ${ }^{50}$ The Court established in its case law on the free movement of goods ${ }^{51}$ and services ${ }^{52}$ that economic grounds cannot serve as a justification for derogations from the Member States' obligations. ${ }^{53}$ As the scope of the Treaty provisions on the four fundamental freedoms has expanded and the Gebhard formula ${ }^{54}$ has been applied consistently in case law relating not just to the freedom of establishment, ${ }^{55}$ the prohibition of using pure economic justifications extends also to measures restricting the free movement of capital. ${ }^{56}$ Accordingly, limitations on capital movements cannot be justified by the financial interests of Member States, ${ }^{57}$ such as strengthening the structure of the market ${ }^{58}$ or primary budgetary objectives. ${ }^{59}$ One issue remains, however, which is the difficulty of obtaining a precise definition of what constitutes strictly economic interests. ${ }^{60}$ As a result, the Court sometimes adopts an 'avoidance strategy', ${ }^{61}$ where it disregards the possible economic justifications of a measure and is satisfied by argumentation based on the general interest of the Member States. ${ }^{62}$

Understanding the basic principles which govern the freedom of capital movement in the context of this article is paramount to reviewing the legality of the Cyprus Investment Programme adequately. Even though the freedom acquired a wide definition, the Court's methods in assessing measures

50 Court of Justice, judgment of 28 September 2006, Joined Cases C-282/04 and C-283/04 Commission of the European Communities $v$ Kingdom of the Netherlands, paras 32-33.

$51 \quad \mathrm{C}-265 / 95$ Commission v France, para 62.

52 Court of Justice, judgment of 5 June 1997, case C-398/95 SETTG, para 23.

53 C-367/98 Commission v Portuguese Republic, para $5^{2}$.

54 Court of Justice, judgment of 30 November 1995, case C-55/94 Reinhard Gebhard v Consiglio dell'Ordine degli Avvocati e Procuratori di Milano, para 37.

55 Court of Justice, judgment of 11 July 2002, case C-294/oo Deutsche Paracelsus Schulen für Naturheilverfaharen GmbH v. K Gräbner, para 39; Court of Justice, judgment of 17 October 2002, case C- 79/o1 Payroll Data Services (Italy) et al, para 28; Spaventa, E. (2004). From Gebhard to Carpenter: Towards a (non-) Economic European Constitution. Common Market Law Review 41, pp. 749-750.

56 Spaventa (n 55), pp. 751; Communication of the Commission on Certain Legal Aspects Concerning Intra- EU Investment [1997] C22o/15, point 9.

$57 \quad$ Horsley (n 41), pp. 167.

$5^{8} \quad$ C-367/98 Commission v Portuguese Republic, para 52.

59 Court of Justice, judgment of 7 February 1984, case 238/82 Duphar BV and others $v$ The Netherlands State, para 23.

6o Snell, J. (2016). Economic Justification and the Role of the State, in Koutrakos, P., Nic Shuibhne, N. and Syrpis, P. (eds), Exceptions from EU Free Movement Law. Hart Publishing, pp. $16-17$.

61 Ibid

62 Ibid; C-120/95 Decker, para 39; C-158/96 Kohll, para 41. 
breaching Article 63 TFEU have now become uniform and systematic. Member States may not limit the ability or dissuade their citizens from liquidating or reallocating their investments without a legitimate reason. Most importantly, this reasoning should not be purely economic, despite the difficulty which exists in identifying wholly economic justifications.

\section{III.2 Application of These Principles to the Cypriot Case}

The Cyprus Investment Programme requires applicants to invest in private immovable property, part of which must be retained in the Republic indefinitely. This particular condition amounts to a de facto barrier to the right of free movement of capital in the form of real estate investments. Cypriots naturalised under this Programme are prevented from exercising their right to move their investment freely, without any restrictions, limitations or unfair repercussions, such as the threat of revocation of their citizenship status. In this context, one cannot disregard the right to property, included in the European Convention on Human Rights ('ECHR'), 63 the Charter of Fundamental Rights of the European Union ${ }^{64}$ as well as the Cyprus Constitution. ${ }^{65}$ The right to own and dispose of lawfully acquired possessions is an intrinsic element in all three articles and while limitations may be imposed, they must be made in the name of public interest and be regulated by law. As the focus of this section is the right to free movement of capital, an analysis of the restriction imposed by the duty to retain property permanently and its possible justifications will proceed.

Firstly, I argue that the Programme lacks any guarantee for the equal treatment of domestic and cross-border capital movements. Those naturalised through this Programme are able to move their investment only within the borders of Cyprus (apart from the TRNC where the government does not exercise effective control); relocation of the investment to other Member States or sale of the property without the immediate purchase of a replacement will result in the revocation of citizenship. Such a requirement is not imposed on other Cypriots. ${ }^{66}$ Secondly, the obligation to retain ownership of residential property in the Republic forever - regardless the fact that it is part of the investment used for naturalisation - can be argued to constitute a violation of Article $63 \mathrm{TFEU}$, if it is considered in light of the non-hindrance test applied

63 Art. 1, Protocol 1 ECHR.

64 Art. 17 (1), Charter of Fundamental Rights of the European Union [2000] C364/1.

65 Art. 23, Constitution of the Republic of Cyprus 196o.

66 See Krakat (n 1), pp. 156. 
in Commission v Belgium ${ }^{67}$ and Commission v Portuguese Republic, ${ }^{68}$ where the Court stated that Article $63 \mathrm{TFEU}$ is breached, if a measure has a deterrent or discouraging effect on individuals seeking to invest abroad. A similar conclusion can be drawn by looking at the judgment in Verkooijen where the applicant was restricted from investing in companies outside the Netherlands ${ }^{69}$ as a result of a measure that did not grant tax exemptions to individuals who receive dividends on shares in foreign companies. ${ }^{70}$ Such a restriction, according to the Court, dissuades individuals from investing their capital in other Member States, ${ }^{71}$ a ruling that can be applied by analogy to the duty to retain ownership of residential property used for investment in exchange for citizenship. Allowing Member States to impose restrictions as such, creates the illusion of the freedom of movement of capital and problems with legal certainty and the uniform application of Union law arise.

Furthermore, by providing Union citizenship, the Programme makes it more attractive for third-country nationals to lock their investment in the Republic, which may gradually lead to the obstruction of free movement of capital to other Member States. Liberalisation of cross-border capital movement within the EU is an intrinsic feature of the internal market and it is essential for the attainment of the socioeconomic objectives of the Union. ${ }^{72}$ Obstruction of the possibility of making the best use of this freedom affects the individuals whose Union rights are violated, but ultimately, it has detrimental effects on the economic prosperity of other Member States, which the Union aims to guarantee. ${ }^{73}$ Despite the fact that the legal requirements for the acquisition

67 The case concerned a Belgian Royal Decree which prohibited Belgian residents from obtaining loans issued by German banks above the fixed rate. In its evaluation of the measure, the Court established that limitations on acquiring loans from other Member States, as well as making investments abroad, constitute violations of Article 63 TFEU; Court of Justice, judgment of 26 September 200o, case C-478/98 Commission v Kingdom of Belgium, paras 3, 18.

68 C-367/98 Commission v Portuguese Republic, paras 44-45.

69 Court of Justice, judgment of 6 June 20oo, case C-35/98 Staatssecretaris van Financiën v B.G.M. Verkooijen, paras 34-35.

70 C-35/98 Verkooijen, paras 6-11; Note that in this case it was established that the receipt of dividends from companies in other Member States is an 'indissociable from a capital movement' (para 29).

$71 \quad$ C-35/98 Verkooijen, para 34.

72 Art. 3(1) TEU; Hindelang (n 42), pp. 10-11; European Commission, National Institute of Economic and Social Research, 'Capital Market Liberalisation' (summary) Single Market Review Series [1996].

73 For an extensive analysis of the socioeconomic benefits of the free movement of capital see Hindelang (n 41), pp. 19-24. 
of EU Citizenship through investment in Cyprus do not take the form of exchange authorization or affect the general possibility of investment abroad, they could constitute an obstacle to the broadest possible liberalisation of the capital movement markets in the EU, as was established in the Brugnoni case. ${ }^{74}$

That said, the possible justifications which could validate the implementation of restrictive measures in the Republic and the derogation from its obligations towards the Union must be examined. The Programme was adopted to overcome the economic challenges after the 2012 financial crisis and to attract foreign investment by encouraging natural persons with high incomes to establish themselves in the Republic. ${ }^{75}$ These are the only explicit objectives found in the government's website and public statements, which I would argue can be considered purely economic motives. The consequences have been indeed positive: increased tax revenue and increased investment in real estate, tourism and development. ${ }^{76}$ Economic prosperity surely resonates with the interest of those individuals who can profit from the clear deficiencies of this Programme, which disadvantages others with respect to Union law. The Cypriot government aims to boost its economy through this Programme and the restriction imposed on applicants would fall under the justification of establishing and maintaining lasting economic links between the investors naturalising and the Republic.

However, justifying such an obvious restriction on capital movement on the basis of achieving economic prosperity would be rather difficult before the Court. As mentioned in the preceding passage, the Court is reluctant to allow justification of a restriction on strictly economic grounds. ${ }^{77}$ Another approach would be to consider the principle of the general interest of the state as an overriding justification. In Decker ${ }^{78}$ and $\mathrm{Kohl}^{79}$ the justification used to restrict

74 Court of Justice, judgment of 24 June 1986, case C-157/85 Brugnoni and Ruffinengo v Cassa di Risparmio di Genova e Imperia, para 22.

75 Cyprus Investment Programme (n 4); Antoniou, G. (2017). Limits on passports to investors, available at http://www.philenews.com/eidiseis/politiki/article/436466/ orio-sta-diabatiria-se-ependytes.

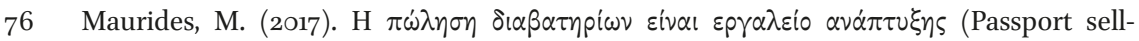
ing is a development tool), available at http://www.sigmalive.com/simerini/analiseis/

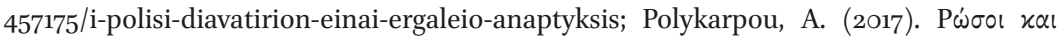

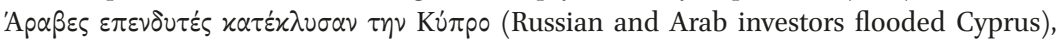
available at https://www.offsite.com.cy/articles/eidiseis/oikonomia/217274-rosoi-kaiaraves-ependytes-kateklysan-tin-kypro-poia-einai-ta; Hadjioannou, B. (2019). €6.6b from citizenship scheme: breakdown of investments, available at https://in-cyprus.com/e6-6bfrom-citizenship-scheme-breakdown-of-investments/.

77 Snell (n 6o).

78 C-120/95 Decker, para 39 .

79 C-158/96 Kohll, para 41. 
the free movement of goods and services respectively was to secure the financial balance of the social security systems. The Court found that neither restriction had any significant effect on the social security system of the Member States in question and then proceeded in examining alternative justifications, by ruling on the general interest of a state, as opposed to focusing on purely economic justifications. ${ }^{80}$ I believe that a similar outcome would result from such an approach during the examination of the conformity of the Cyprus Programme with Article 63 TFEU. Alternatively, the Court would find the justifications used by the Cyprus government as strictly economic. Either way, requiring individuals to retain their investment in Cyprus indefinitely raises serious concerns in view of the right to move capital freely within the Union: such a limitation constitutes a violation of the Republic's obligations under the Treaties and surviving the judicial scrutiny of the Court can be difficult.

\section{Citizenship of the EU}

\section{IV.1 Investment Migration Schemes in the EU and the Evolving Nature of Union Citizenship}

Examining investment migration schemes in the framework of the EU legal order can be challenging, considering the unconventional character EU citizenship acquired. It was recognised as the intended future fundamental status of Member States' nationals in $1992^{81}$ and ever since, made the complicated relationship between the supranational EU and national legal orders even more profound. Prima facie, agreeing with Jo Shaw, there is no legal basis for EU-level opposition to investment migration programmes, ${ }^{82}$ because of the derivative nature of Union citizenship. ${ }^{83}$ Nevertheless, different nationality laws have always raised concerns within the Union, as the result of granting the unifying EU citizenship status to third-country nationals would be the availability of EU rights such as freedom of movement, which ultimately affects all Member States. ${ }^{84}$ In 2014 the European Parliament, while underlining its own lack of

80 C-120/95 Decker, paras 40-41; C-158/96 Kohll, paras 42-43.

81 Art. 8, Treaty on European Union [1992] OJ C191/1; Court of Justice, judgment of 20 September 2001, case C-184/99 Rudy Grzelczyk v Centre public d'aide sociale d'OttigniesLouvain-la-Neuve, para 31; Court of Justice, judgment of 17 September 2002, case C-413/99 Baumbast and R, para 82.

82 Shaw, J. (2018). Citizenship for Sale: Could and Should the EU Intervene? in Bauböck, R. (ed) Debating Transformations of National Citizenship. Springer, Cham 2o18, pp. 63-64.

83 Art. 20 TFEU.

84 Kochenov (n 7), pp. 182-183. 
legal competences over this matter, ${ }^{85}$ adopted a Resolution on EU Citizenship for sale in response to the Maltese Individual Investors Programme (hereafter the 'IIP'), where it expressed its concerns at the development of investment migration in the EU and requested the Commission to examine their legality. ${ }^{86}$

Attention must also be paid to the principle of recognition of other Member State nationalities, regardless of their mode of acquisition, developed in Micheletti. ${ }^{87}$ Accordingly, Member States have to respect the EU citizenship status of nationals from other Member States as well as the nationality of their own citizens. ${ }^{88}$ This line of reasoning was previously indicated in Auer, where the Court ruled that:

There is no provision of the Treaty which [...] makes it possible to treat nationals of a Member State differently according to the time at which or the manner in which they acquired the nationality of that State $[.]^{89}$

This is crucial to the development of investment migration and the concerns raised by Member States that such practices affect the entire Union. According to Auer and Micheletti, the mode of naturalisation is irrelevant to the validity and recognition of the EU citizenship status of an individual by other Member States and any distinction between groups of nationals of Member States made in this regard shall be deemed unacceptable. ${ }^{90}$ The CJEU's approach to the recognition of Member States' nationalities makes investment migration schemes perfectly legitimate: 'investment Cypriots' - just as the 'investment Maltese' - are full-fledged citizens of the EU. In addition, the argument proposed by the AG Poiares Maduro in Rottmann, ${ }^{91}$ that mass naturalisations of third-country nationals could contradict the principle of sincere cooperation ${ }^{92}$

85 European Parliament resolution of 16 January 2014 on EU citizenship for sale, 2013/ 2995(RSP), recital 7.

86 European Parliament resolution of 16 January 2014 on EU citizenship for sale, 2013/ 2995(RSP), recitals 1, 3; Surak (n 3), pp. 25; 'Malta Citizenship by Investment Program' available at http://www.maltaimmigration.com.

87 C-369/9o Micheletti, para 10; Kochenov (n 7), pp. 182.

88 Jessurun d'Oliveira, H.-U. (1993). Case C-369/9o Mario Vicente Micheletti and others v Delegación del Gobierno en Cantabria, Judgment of 7 July 1992. Common Market Review 3о, pp. 628.

89 Court of Justice, judgment of 7 February 1979, case C-136/78 Ministere Public v. Auer, para 28 (emphasis added).

90 Art. 5(2), European Convention on Nationality (1997) ETs 166; de Groot, D.A.J.G. (2018), Free Movement of Dual EU Citizens, European Papers 3, pp. 1105.

91 C-135/o8 Rottmann.

92 Art. 4(3) TEU. 
if not performed in consultation with other Member States, ${ }^{93}$ seems inapplicable to the case of investment schemes, given that the number of naturalisations through investment in the EU remain low, especially compared with analogous situations, such as the large numbers of Latin Americans naturalised as Italians. ${ }^{94}$ Even if these numbers were to grow in the future, we must consider that third-country nationals naturalising in any Member State through investment migration schemes are individuals of high net worth who would not impose an 'unreasonable burden' on the social welfare systems of Member States if they were to decide to use their free movement rights according to the Citizenship Directive. ${ }^{95}$ These individuals contribute to the functioning of the internal market and the objectives of European economic integration, making them valuable citizens in light of EU's unfortunate internal market logic. ${ }^{96}$

The rights attached to the status of EU citizenship were initially manifested in activity within the internal market through the free movement rights, ${ }^{97}$ which explains the Court's insistence on the requirement for cross border movement to ascertain the applicability of Union law in citizenship cases. ${ }^{98}$

93 C-135/o8 Janko Rottmann v Freistaat Bayern [2010] ECR I-o1449, Opinion of AG Poiares Maduro, para 30.

94 Kochenov, D. (2018). Citizenship for Real: Its Hypocrisy, Its Randomness, Its Price, in Bauböck, R. (ed), Debating Transformations of National Citizenship. Springer, Cham, pp. 54; Tintori, G. (2011). The Transnational Political Practices of "Latin American Italians" IOM 49, pp.172-173; Surak (n 3), pp. 6.

95 Art. 7(1)(b), Council Directive 2004/38/EC of 29 April 2004 on the right of citizens of the Union and their family members to move and reside freely within the territory of the Member [2004] OJ L 158 30.4.2004; Heindlmaier, A. and Blauberger, M. (2017). Enter at your own risk: free movement of EU citizens in practice. West European Politics 40, pp. 1200-1201; Thym, D. (2015). The Elusive Limits of Solidarity: Residence Rights of and Social Benefits for Economically Inactive Union Citizens. Common Market Law Review 52, pp. 20.

96 Kochenov, D. (2017). On Tiles and Pillars: EU Citizenship as a Federal Denominator, in Kochenov D. (ed) EU Citizenship and Federalism: the Role of Rights. Cambridge University Press, pp. 36-39; Kochenov, D. (2019). Interlegality - Citizenship - Intercitizenship, Forthcoming in Palombella, G.and Klabbers J. (eds), The Challenge of Interlegality. Cambridge University Press, pp. 70.

97 Kostakopolou, D. (2005). Ideas, Norms and European Citizenship: Explaining Institutional Change. The Modern Law Review 68, pp. 238-239; Yanasmayan, Z. (2009). European Citizenship: A Tool for Integration, in Carrera, S., Groenendijk, K. and Guild, E. (eds), Illiberal Liberal States: Immigration, Citizenship and Integration in the EU, Routledge, pp. 68; Spaventa, E. (2017). Earned Citizenship - Understanding Union Citizenship through its Scope, in Kochenov, D. (ed), EU Citizenship and Federalism: The Role of Rights. Cambridge University Press, pp. 206-207.

98 Nic Shuibhne, N. (2010). The Resilience of EU Market Citizenship. Common Market Law Review 47(6), pp. 1597, 1612. 
The cross-border rationale continues to exist but is now broadened by the inclusion of potential cross-border movement and with added emphasis on individual rights through the expansion of the material and personal scope of Union citizenship through the case law of the CJEU..$^{99}$

Rottmann $n^{100}$ is of utmost importance in this respect. The Court for the first time provided a clarification of the principle 'due regard to Community law', established in Micheletti. ${ }^{101}$ Essentially, the ruling resulted in limiting the Member States' discretion in measures revolving around the grant and revocation of nationality by introducing the principle of proportionality to the decisions taken by national authorities: ${ }^{102}$ this led to the reassessment of the interdependent relationship between national and EU citizenship. ${ }^{103}$ Despite AG Poiares Maduro's suggestion that a cross-border element is a prerequisite to trigger EU law, the Court's approach to this case was different. ${ }^{104}$ Accordingly, a situation in which an individual is faced with a decision withdrawing their naturalisation falls 'by reason of its nature and its consequences within the ambit of EU law'105 The Court's departure from the traditional requirement of cross-border movement indicates a shift of emphasis to the protection of the individual, who is placed in a situation where they lose the status conferred by

99 Ibid, pp. 1612, 1613-1614; Kochenov (14), pp. 59-6o.

100 C-135/o8 Rottmann.

101 In Micheletti the Court mentioned the principle 'due regard to community law' but it was perceived as obiter dictum of the ruling; de Groot, G.-R. (2004), Towards a European Nationality Law, EJCL, 8; Jessurun d'Oliveira (n 88), pp. 634.

102 C-135/o8 Rottmann, para 55. For more information on the principle of proportionality see Rochel, J. (2019). Working in Tandem: Proportionality and Procedural Guarantees in EU Immigration Law, German L.J. 2 o.

103 Mann, D.-J. and Purnhagen, K. P. (2011). The Nature of Union Citizenship between Autonomy and Dependency on (Member) State Citizenship - A Comparative Analysis of the Rottmann Ruling, or: How to Avoid a European Dred Scott Decision. Wisconsin International Law Journal 29, pp. 491-493; Shaw, J. (2018). Deprivation of Citizenship: Is There an Issue of EU Law? in Bauböck, R. (ed) Debating Transformations of National Citizenship. Springer, Cham, pp. 236-238.

104 C-135/o8 Rottmann v Freistaat Bayern, Opinion of AG Poiares Maduro, paras 10, 14, 23; Kochenov, D. (2010). Case C-135/o8, Janko Rottmann v. Freistaat Bayern, Judgment of the Court (Grand Chamber) of 2 March 2010, not yet reported. Common Market Law Review 47, pp. 1832-1833; Kostakopoulou, D. (2012). The European Court of Justice, Member State Autonomy and European Citizenship: Conjunctions and Disjunctions, in Micklitz, H.W. and de Witte, B. (eds), The European Court of Justice and the Autonomy of the Member States. Intersentia, pp. 198-199.

105 C-135/o8 Rottmann, para 42; van Eijken, H. (2010). European Citizenship and the Competence of Member States to Grant and to Withdraw the Nationality of their Nationals. Utrecht Journal of International and European Law 27, pp. 68-69. 
Article 20 TFEU and the rights attached thereof. ${ }^{106}$ By bringing Dr Rottmann's case within the scope of EU law, the Court effectively expanded the ratione materiae of EU citizenship. ${ }^{107}$ As a result, the need to exercise free movement rights is no longer the paramount requirement for the ECJ to intervene; based on Rottmann, the status of being a Union citizen and the rights associated with it became sufficient foundation to engage and determine any violations of EU law, which reaffirms its fundamental status, established in Grzelczyk.108

Another critical case which builds on the Rottmann line of reasoning is Ruiz Zambrano. ${ }^{109}$ This case dealt with the decision of the Belgian authorities to deprive the residency and working rights of Mr Ruiz Zambrano, a Colombian national and parent of two children born in Belgium. ${ }^{110}$ The ECJ insisted on the applicability of the case under EU law, despite the absence of crossborder movement, because Mr Zambrano's children were Union citizens and would be deprived of 'the genuine enjoyment of the substance of [their] rights'111 if forced to move outside the territory of the Union. ${ }^{112}$ Unfortunately, in following cases the Court adopted a more restrictive approach to situations which potentially deprive individuals of the substance of their Union citizenship rights, ${ }^{113}$ by qualifying the ruling in Ruiz Zambrano as an exceptional

106 Kochenov (n 14), pp. 58-61; C-135/o8 Rottmann, para 42; Garner, O. (2018). The Existential Crisis of Citizenship of the European Union: The Argument for an Autonomous Status. Cambridge Yearbook of European Legal Studies 20, pp. 126.

107 Kochenov (n 14), pp. 64 and 67-69.

108 Cambien, N. (2011). Case C-135/o8 Janko Rottmann v. Freistaat Bayern. Columbia Journal of European Law 17, pp. 383-384; Bauböck, R. and Paskalev, V. (2014). Cutting Genuine Links: A Normative Analysis of Citizenship Deprivation, Geo. Immigr. L.J. 30 (47), pp. 99 and 102; Jessurun d'Oliveira, H.-U. (2018). Once again: Plural nationality. Maastricht Journal of European and Comparative Law 25, pp. 37; Jessurun d'Oliveira in this volume.

109 C-34/og Ruiz Zambrano.

110 C-34/og Ruiz Zambrano, paras 14-16, 43-44.

111 C-34/og Ruiz Zambrano, paras 40-44; Lansbergen, A. and Miller, N. (2011). Court of Justice of the European Union European Citizenship Rights in Internal Situations: An Ambiguous Revolution? Decision of 8 March 2011, Case C-34/og Gerardo Ruiz Zambrano v Office national de l'emploi (ONEM). European Constitutional Law Review 7, pp. 291.

112 Nic Shuibhne, N. (2012). (Some of) The Kids Are All Right. Common Market Law Review 49, pp. 350-352; Hailbronner K. and Thym, D. (2011). Case C-34/o9, Gerardo Ruiz Zambrano v. Office national de l'emploi (ONEm), Judgment of the Court of Justice (Grand Chamber) of 8 March 2011, not yet reported. Common Market Law Review 48, 1255-1257.

113 C-434/og McCarthy, paras 46-47; Court of Justice, judgment of 29 September 2011, case C-256/11 Murat Dereci and Others v Bundesministerium für Inneres, paras 40, 74; Spaventa, E. (2017). Earned Citizenship - Understanding Union Citizenship through its Scope, in Kochenov, D. (ed), EU Citizenship and Federalism: The Role of Rights. Cambridge University Press, pp. 212-213. 
case. ${ }^{114}$ In the recent case of Tjebbes, ${ }^{115}$ despite the effort to follow the principles established in previous case law on EU citizenship, the Court ruled that a measure revoking Dutch and EU citizenship of Dutch nationals, who possess another nationality and who resided outside the Union for more than ten consecutive years, without renewing their passport within that period, is compatible with EU law as long as the proportionality test is performed by the national authorities and courts. ${ }^{116}$ The vagueness and the passing manner by which the principles of EU citizenship have been applied by the Court, resulted in a missed opportunity to clarify and strengthen the already established principles on EU citizenship. ${ }^{117}$ Notwithstanding that, the formula of 'substance of rights' established in Ruiz Zambrano, though uncertain, remains promising ${ }^{118}$ and is regarded as a stepping stone on the way to shaping the material scope of Union law by defending the future ability of individuals to enjoy their EU rights. ${ }^{119}$

The judgments in Micheletti, Rottmann and Ruiz Zambrano pave the way towards a better understanding of the relationship between national and Union citizenship. ${ }^{120}$ With the expansion of the scope of EU citizenship ratione materiae, the requirement of cross-border movement is proven illogical ${ }^{121}$ in a 'Union without borders' and contrary to the spirit of European integration. ${ }^{122}$ In the current context, three conclusions can be drawn which will provide guidance in the assessment of the Cyprus Programme. Firstly, Member State nationality must be recognised and respected by all Member States (including the Member State issuing the nationality), ${ }^{123}$ regardless the mode of

114 C-256/11 Dereci, para 55; Nic Shuibhne, N. (2015). Limits Rising, Duties Ascending: The Challenging Legal Shape of Union Citizenship. Common Market Review 52, 901-902; Skrbic, A. (2019) Mobile Individualism: The Subjectivity of EU Citizenship, Neth. J. Legal. Phil. 48, pp. $25^{-26 .}$

115 Court of Justice, judgment of 12 March 2019, case C-221/17 M.G. Tjebbes and Others $v$ Minister van Buitenlandse Zaken.

$116 \mathrm{C}-221 / 17$ Tjebbes, paras 39-40.

117 Kochenov, D. (2019), The Tjebbes Fail, European Papers 4, 326.

118 Sánchez, S. I. (2014). Fundamental Rights and Citizenship of the Union at a Crossroads: A Promising Alliance or a Dangerous Liaison? European Law Journal 2o, pp. 474.

119 Kochenov, D. (2013). The Essence of EU Citizenship Emerging from the Last Ten Years of Academic Debate: Beyond the Cherry Blossoms and the Moon? International and Comparative Law Quarterly 63, pp. 101.

120 Kochenov (n 14), pp. 86; Krūma, K. (2015). EU Citizenship, Nationality and Migrant Status: An ongoing Challenge. Brill Nijhoff, pp. 124.

121 Kochenov (n 14) pp. 92-93.

122 Kochenov, D. (2010). Citizenship without Respect: The EU's Troubled Equality Ideal.Jean Monnet Working Paper 08/10, pp. 43-44.

123 Ibid. 
naturalisation. Secondly, even though the derivative nature of EU citizenship is uncontested, the need to preserve its unique status and protect the individuals' rights requires limitations on Member State competences in matters of citizenship, particularly when EU rights are undermined by a measure adopted at the national level. Thirdly, Member States should not impose restrictive conditions on their own citizens, the effects of which would be to render the future prospect of exercising their Union rights impossible.

\section{IV.2 The Cyprus Investment Programme: Revocation of Union Citizenship, Discrimination, Family Members and the Right to Leave}

The adoption of investment migration schemes in Member States is not uncommon and, as has been established in the previous passage, does not necessarily violate Union law. However, the Cyprus Investment Programme is significantly different due to the requirement imposed on investors to retain ownership of residential property in the Republic for an unlimited period. This condition can cause future complications, as it places individuals who decide to sell their invested property or to relocate beyond the island's territory in a situation where their Cypriot nationality and EU citizenship will be revoked. ${ }^{124}$ The conditional nature of the citizenship acquired through investment ${ }^{125}$ prompts several issues when viewed in the light of EU citizenship law: the ability of Cyprus to revoke citizenship upon the exercise of rights granted by EU law and the consequences such measures would have on the investor's family.

The revocation of citizenship based on non-compliance with the conditions of the Cyprus Programme must be closely analysed, mainly in light of

124 Cyprus Investment Programme (n 4) 1.

125 'Conditional Citizenship' is not merely a Cypriot invention; the UK adopted a similar approach and according to the 2006 Immigration, Asylum and Nationality Act, deprivation of citizenship constitutes a valid measure that can be taken by the Secretary of State of the Home Department in an attempt to "fight terrorists 'disguised' as UK citizens". The difference between the UK and Cyprus is that firstly, the conditionality of the British citizenship applies to all citizens, regardless whether they acquired their nationality by birth or through registration and naturalisation and secondly, this conditionality is activated when a citizen engages in terrorist activity; thus the deprivation is seen as a form of a punitive measure to protect national security. In Cyprus on the contrary, the conditional nature applies only to investor Cypriots who exercise their right to the free movement of capital by re-investing outside the Republic's territory. See Mantu, S. (2010). 'Terrorist' citizens and the human right to nationality. Journal of Contemporary European Studies 26, pp. 32-33; Lavi, S. (2010). Punishment and the Revocation of Citizenship in the United Kingdom, United States, and Israel. New Criminal Law Review: An International and Interdisciplinary Journal 13, pp. 409-411; Joppke, J. (2015). Terror and the Loss of Citizenship. Citizenship Studies 20, 733--734. 
Rottmann and Ruiz Zambrano. In Rottmann the Court concluded that Member States must take decisions on the revocation of nationality having due regard to Community law, and proceeded to delegate the proportionality test to the German court. ${ }^{126}$ On the one hand, empowering national courts with the application of the principle of proportionality could undermine the principle of legal certainty for individuals and threaten the uniform application of Union law. ${ }^{127}$ On the other hand, it can be considered as an efficient method of allowing cooperation between the national courts of the Member States and the CJEU, once the latter establishes its jurisdiction and the potential breach of the substance of EU citizenship rights. ${ }^{128}$ In Rottmann the national courts found that the revocation of Dr Rottmann's citizenship was proportionate because of his criminal history and the fact that it did not breach any international or EU law requirements. ${ }^{129}$

Notwithstanding the discretion Member States enjoy in nationality matters, measures regarding the withdrawal of nationality must be legitimate in light of EU law. ${ }^{130}$ When comparing the argumentation and the outcome of Rottmann to the Cyprus case, fundamental differences must be pointed out. To begin with, the decision of an individual to exercise their Union rights and relocate their investment outside the territory of a Member State cannot be compared to the situation in Rottmann, where the applicant was found guilty of obtaining German nationality by deception. ${ }^{131}$ Consequently, the revocation of nationality was considered legitimate in the name of protecting the solidarity between all the citizens of Germany. In the Cyprus case nationality is withdrawn as a consequence of the decision from $\mathrm{Cy}$ priots naturalised through investment to move their capital away from the territory of Cyprus, relying on Articles 26 and 36 TFEU. The revocation of Cypriot nationality for non-compliance with the condition to permanently

126 C-135/o8 Rottmann, paras 58-59.

127 In Rottmann, before delegating the competence to the German court, the ECJ included some suggestions on how to assess proportionality which made the outcome of the German ruling more predictable, see C-135/o8 Rottmann [2010], para 56; van Eijken, H. (2010). European Citizenship and the Competence of Member States to Grant and to Withdraw the Nationality of their Nationals. Utrecht Journal of International and European Law 27, pp. 69; van der Mei, A. P. (2018). EU Citizenship and Loss of Member State Nationality. European Papers 3, pp. 1323.

128 Kochenov, D. and Plender, R. (2012). EU Citizenship: From an Incipient Form to an Incipient Substance? The Discovery of the Treaty Text. European Law Review 37, pp. 386 and 392-393.

129 Kochenov (n 14), pp. 78.

130 C-135/o8 Rottmann, para 51; Shaw (n 103), p. 235.

131 C-135/o8 Rottmann, para 28. 
own property in Cyprus is a restriction of the EU right to free movement of capital and the possibility of this measure being justified is very unlikely, as was established in the previous section on capital movement. The measure also restricts the applicants' right leave the territory of Cyprus and establish themselves in other Member States. Łazowski argues that the right to exit is a condition sine qua non to the right to move and reside freely within the Union, ${ }^{132}$ as it is implied in Article 21 TFEU. The right to exit is also established in Article 4 of the Citizenship Directive ${ }^{133}$ and was affirmed by the Court in Jipa and subsequent cases, in which individuals were prevented from leaving their Member State of nationality. ${ }^{134}$ This right is compromised by the Investment Programme as it practically ties the applicants to the Republic, making the exercise of the right to move freely to other Member States unappealing. Even if this does not amount to a direct restriction to the right to leave, it is nonetheless incompatible with the objective to eliminate any obstacles to free movement within the EU, a prerequisite to the functioning of the internal market. ${ }^{135}$

Adopting a naturalisation programme on the basis of limiting the exercise of rights accorded by EU law is contrary to the spirit of the Treaties as it interferes with the goal of gradual integration even if, paradoxically, the Cyprus Investment Programme presents it under a pretext of enhancing economic integration. Based on the judgment in Lounes ${ }^{136}$ it is 'contrary to the underlying logic of gradual integration that informs Article 21(1) TFEU

132 Łazowski, A. (2015). Darling you are Not Going Anywhere: The Right to Exit and Restriction in EU Law. European Law Review 47, pp. 888.

133 Art. 4, Council Directive 2004/38/EC of 29 April 2004 on the right of citizens of the Union and their family members to move and reside freely within the territory of the Member [2004] OJ L 158 30.4.2004.

134 Court of Justice, judgment of 10 July 2008, case C-33/o7 Ministerul Administratiei si Internelor - Directia Generala de Pasapoarte Bucurestiv Jipa, para 18; This line of reasoning continued in subsequent judgments, see Court of Justice, judgment of 17 November 2011, case C-430/10 Gaydarov v Direktor na Glavna Direktsia Ohranitelna Politsia pri Ministerstvo na Vatreshnite Raboti and Court of Justice, judgment of 17 November 2011, case C-434/10 Aladzhov v Zamestnik Direktor na Stolichna Direktsia na Vatreshnite Raboti kam Ministerstvo na Vatreshnite Raboti.

135 Court of Justice, judgment of 25 July 2008, case C-127/08 Blaise Baheten Metock and Others $v$ Minister for Justice, Equality and Law Reform, para 68; de Groot, G.-R. and Steling, A. (2011). The Consequences of the Rottmann Judgment on Member States Autonomy The Court's Avant-Gardism in Nationality Matters, in Shaw, J. (ed), Has the European Court of Justice Challenged Member State Sovereignty in National Law? EUI RSCAS 2011/62.

136 Court of Justice, judgment of 14 November 2017, case C-165/16 Toufik Lounes $v$ Secretary of State for the Home Department, paras 56-58; Kochenov (n 7), pp. 191-192. 
to hold that such citizens, who have acquired rights under that provision as a result of having exercised their freedom of movement, must forego those rights.'.137

Through the case law on citizenship, the Court established itself as the final arbitrator and protector of EU citizens through the activation of EU law when national measures result to the loss of the rights attached to the status of Union citizenship ${ }^{138}$ and as a result, decision-making and the adoption of policies such as the Cyprus Investment Programme no longer fall under the sovereignty umbrella. Potential violations of the substance of Union citizenship can be manifested through restrictions to the exercise of one of the fundamental rights of the Treaties ${ }^{139}$ and are amplified when a Member State's naturalisation process leads to the granting of Union citizenship status which is absurdly conditioned by a limitation of the rights it is associated with. The priority to enact measures which would result in relative economic prosperity should not overshadow the arbitrary effects of such measures on individuals' rights. The interests of other Member States must also not be ignored: using a measure such as the withdrawal of nationality if individuals decide to exercise their right to the free movement of capital is burdensome to say the least and contrary to the aim of achieving a functioning internal market within the EU. ${ }^{140}$ Based on these findings, one must conclude that a measure withdrawing the naturalisation of an EU citizen on the basis of exercising their right to the free movement of capital alongside their right to exit, cannot be considered legitimate.

In addition to the effects on the main investor, family members are also greatly affected by this Investment Programme. Citizenship is granted initially to the main investor and subsequently can be acquired by their parents, spouse or partner and by their financially dependent adult children, ${ }^{141}$ while their minor children naturalise in accordance with Article 110(3) Civil Registry

137 C-165/16 Lounes, para 58; de Groot (n 135), pp. 1104; Shaw, J. (2018). EU citizenship: still a fundamental status? European University Institute (RSCAS 2018/14), pp. 7.

138 Lenaerts, K. (2012). Civis Europaeus Sum: From the Cross-border Link to the Status of Citizen of the Union, in Rosas, A., Wahl, N., Lindh, L. and Cardonnel, P. (eds) Constitutionalising the EUJudicial System: Essays in Honour of Pernilla Lindh. Oxford Hart Publishing, pp. 141-142.

139 de Groot, G.-R. (2004). Towards a European Nationality Law. EJCL 8.

140 Art. 26 TFEU; Hindelang (n 42), pp. 10-11.

141 'Cyprus Investment Programme (n 4) 1. For clarification, adult dependent children of the applicants are considered students under the age of 28 and children with severe physical or mental disability (see page 2 ). 
Law. ${ }^{142}$ However, there is no mention of the circumstances under which the family members lose their nationality. The extent of their dependency on the investor's citizenship is unclear and their legal status is questionable if the citizenship of the former is revoked because of future non-compliance with the conditions of the Programme. Relying on the Citizenship Directive ${ }^{143}$ would only be possible if the family moves to another Member State and satisfied the criteria of Articles 7(1) and 14(2). ${ }^{144}$ The predicament here is that, if the family wished to exercise the right to relocate within the Union by relying on the Directive, it is very likely that the residential property forming part of their investment would be sold in Cyprus and at most, be reinvested in another Member State. This case, based on the wording of the Programme, would lead to the revocation of at least the main investor's citizenship, and most likely that of all family Members except for minor children naturalised under the ordinary national naturalisation procedures noted above. Therefore, the possibility to acquire or retain residency rights and invoke the right to family reunification becomes ambiguous, as the beneficiaries of the Directive remain Union citizens and their family members. ${ }^{145}$

The Programme also fails to detail the effects of the loss of the Union citizenship of the main investor and their family on future generations. If the nationality of both parents is revoked in accordance with the Programme, their children, born in Cyprus and therefore Cypriot citizens iure soli, would be forced to leave the territory of the Union and thus be deprived of the substance of their Union rights analogously to the situation in Ruiz Zambrano. ${ }^{146}$ One of the questions submitted to the Court in Tjebbes, ${ }^{147}$ was whether it is in conformity of EU law to have minors lose their citizenship status as a

142 Art. 110(3) Civil Registry Law 114(I)/2002 provides that minor children of a citizen of the Republic may acquire Cypriot nationality upon a request made to the Ministry of Internal Affairs.

143 Article 6 and 7 , Council Directive 2004/38/EC of 29 April 2004 on the right of citizens of the Union and their family members to move and reside freely within the territory of the Member [2004] OJ L $15^{8}$ 30.4.2004.

144 Court of Justice, judgment of 21 December 2011, Joined Cases C-424/10 and C-425/ 10 Tomasz Ziolkowski and Barbara Szeja and Others v Land Berlin, paras 40-41; Jesse, M. (2012). Joined Cases C-424/10, Tomasz Ziolkowski v. Land Berlin, and C-425/10, Barbara Szeja, Maria-Magdalena Szeja, Marlon Szeja v. Land Berlin, Judgment of the Court of Justice (Grand Chamber) of 21 December 201. Common Market Law Review 49, pp. 2008.

145 Art. 3, Council Directive 2004/38/EC of 29 April 2004 on the right of citizens of the Union and their family members to move and reside freely within the territory of the Member [2004] OJ L 158 30.4.2004; de Groot (n 9o), pp. 1092-1093; C-165/16 Lounes, para 35.

146 C-34/og Ruiz Zambrano, paras 40-44.

$147 \mathrm{C}-221 / 17$ Tjebbes. 
consequence of the deprivation of the nationality of their parent. In his opinion, AG Mengozzi considered that the principle of uniform nationality within the same family should not be burdensome on the substantive rights and interests of minors, which must be recognised as being independent from those of their parents. ${ }^{148}$ On the other side, the Court ruled that as long as the decision withdrawing the nationality of a minor is seen in light of Article 24 of the Charter, such a decision can be legitimate. ${ }^{149}$ Having regard that a minor loses their citizenship as a consequence of the deprivation of their parent's citizenship, the only logical assumption to an illegitimate decision to revoke the nationality of the parent is that the child is losing their nationality illegitimately as well. ${ }^{150}$ Depriving the status of Union citizenship of minors born in a Member State on the basis of an unjustified revocation of the nationality of their parents seems highly inappropriate and any justification based on economic grounds or the discretion accorded to Member States to govern their nationality laws would contradict the approach taken and the aims pursued by the Court in Ruiz Zambrano.

Non-compliance with the requirement of retaining the invested residential property in the Republic will result in the withdrawal of the investor's Cypriot and EU citizenship and have a knock-on effect on their family members. The ambiguity of the Programme permits the strict interpretation of its provisions, which leads to the following conclusions: the investor and their family members acquire a very peculiar Union citizenship, the validity of which depends on limiting the rights accorded to all EU citizens and the revocation of which exposes the entire family to a regime with which fails to provide for legal remedies.

We must consider whether alternative, more appropriate measures could be taken to integrate newly naturalised investors and at the same time achieve the goal of economic prosperity and development. The main difference between the Cyprus Investment Programme and other investment migration schemes is the conditional character of the citizenship granted to investors, since the requirement of withholding the residential property has no time limitation ${ }^{151}$ and non-compliance results in the revocation of their nationality. ${ }^{152}$ Imposing a reasonable time limit on the ownership of the residential property would

\footnotetext{
$148 \mathrm{C}-221 / 17$ Tjebbes, Opinion of Advocate General Mengozzi paras 122-125.

$149 \mathrm{C}-221 / 17$ Tjebbes, para 47.

150 Bauböck and Paskalev (n 108), pp. 83-85.

$15^{1}$ Cyprus Investment Programme (n 4), pp. 3-4.

$15^{2}$ Cyprus Investment Programme (n 4), pp. 1-2.
} 
not raise concerns in the domain of the free movement of capital. ${ }^{153}$ The absolute prohibition from selling the residential property used as an investment for the purposes of naturalisation in the Republic contradicts the very essence of investment, which is conditioned on the prospect of future liquidity. ${ }^{154}$ Moreover, the programme needs to become more specific on the manner in which citizenship is revoked and provide for a possibility of reviewing such a decision in a procedure that aims to protect the fundamental rights of those affected, having due regard to Union law.

It might be a tough task to balance the economic benefits of a measure, which has indeed succeeded in generating EUR 4.8 billion in investment as of March 2018, ${ }^{155}$ with its adverse effects on individuals, while taking into account the established case law focusing on the deprivation of EU citizenship. It is my view, that the nature of the citizenship granted to investors and the limitations imposed on them demonstrates an unreasonable violation of the substance of Union citizenship, as established by the CJEU's jurisprudence. ${ }^{156}$ With the evolution of a 'new logic of citizenship',157 the importance of Union law and principles shall not be underestimated by national authorities when exercising their competences in matters of naturalisation.

\section{Conclusions}

The legal analysis of the Cyprus Investment Programme in light of EU law on the free movement of capital and citizenship has proven that there is an immediate need for amendments and improvements, which will not only guarantee compliance with Union rules but also advance the benefits for the economy of Cyprus and possibly secure its continuation in the future.

With regards to the question whether the Programme imposes restrictions to the free movement of capital, the case law of the ECJ demonstrates that, inasmuch as economic objectives cannot justify derogations from the obligation

\footnotetext{
153 Limitations to the free movement of capital are allowed for a certain periods of time, according to art. 3(4) and 6 of Council Directive 88/361/EEC of 24 July 1988 for the implementation of Article 67 of the Treaty [1988] OJ L 178/5.

154 UBs. (2017). The Liquidity of Real Estate Investments: Investor Challenges During the Real Estate Cycle. White Paper, pp. 5 .

155 Farolf, S., Harding, L. and Orphanides, S. (2018). EU Citizenship for sale as Russian oligarch buys Cypriot passport, available at https://www.theguardian.com/world/2018/mar/ o2/eu-citizenship-for-sale-as-russian-oligarch-oleg-deripaska-buys-cypriot-passport.

156 C-34/og Ruiz Zambrano, paras 40-44.

157 Kochenov, Plender (n 128), pp. 387.
} 
to prohibit measures that would result in a restriction to the freedom guaranteed in Article $26 \mathrm{TFEU}$, advancing the national economy through a stream of foreign investment, part of which must be kept indefinitely in Cyprus, violates Article 63 TFEU. Therefore, the Programme must be reformed and the requirement to maintain residential property in the Republic indefinitely must be altered with the introduction of time limitations. The overall wording of the Programme should also be more precise, offering individuals all the legal remedies needed in case their citizenship is revoked.

As for the question of the possible violations of EU citizenship law, this article finds that the requirements of the Cyprus Investment Programme are dubious to say the least. The liberalisation of Union citizenship from its traditional establishment in the Treaties through the case law of the CJEU has played a detrimental role in the decisions Member States can take in matters regarding the grant and revocation of nationality. The judgments of Rottmann, Ruiz Zambrano and Lounes guided the process of the evaluation of the Cyprus Programme and accordingly, the revocation of Cypriot nationality and EU citizenship as a result of non-compliance with the condition to retain part of the investment in the Republic forever is illegitimate and unjustifiable, as it leads to the revocation of Union citizenship based on the exercise of the rights it grants access to and leaves the investor's entire family unprotected and with no other alternative but to leave the territory of the Union.

Naturalisation should be a transparent and just process, regardless of the financial status of individuals. As a Member of the EU, Cyprus is under an obligation to follow Union principles such as sincere cooperation and loyalty and is required to eliminate any unjustified obstacles to the free movement of capital. Current and future legislators and other public authorities adopting measures on matters of naturalisation and citizenship in general should remember that serving national economic interests should not restrict fundamental EU rights. The increasing significance of the supranational character of Union citizenship proves that compliance is not a mere formalistic obligation imposed on the Member States: the objectives of the Union ${ }^{158}$ must be internalised and prioritised in every national policy of the Member States. Effective cooperation between national and EU authorities is the best way to adequately shape and preserve the essence of EU citizenship and define the extent to which EU institutions can intervene in the sovereign powers of the Member States. The Cyprus Investment Programme is just one example of the discrepancies that emanate from the uncertainty and disparity in the ECJ's case law. Be that as

$15^{8}$ Art 3 TEU. 
it may, the Court is not solely to blame for the troubled development of EU citizenship; national authorities which continue to disregard the supranational character of the Union are also accountable for the current state of affairs. Instead of contemplating methods to profit from systemic inadequacies, both legal orders must work together to prioritise individual rights, the protection of which both are pledged to guarantee. 